DOI: $\square$ https://doi.org/10.15407/techned2020.01.071

\title{
ENERGY-EFFICIENT CONTROL OF PUMP UNITS BASED ON NEURAL-NETWORK PARAMETER OBSERVER
}

$\quad$ Journal
Publisher
ISSN
Issue
Pages

\author{
Tekhnichna elektrodynamika \\ Institute of Electrodynamics National Academy of Science of Ukraine \\ 1607-7970 (print), 2218-1903 (online) \\ No 1, 2020 (January/February) \\ $71-77$
}

\author{
Authors \\ S.O. Burian ${ }^{1 \star}$, O.I. Kiselychnyk ${ }^{2 \star \star}$, M.V. Pushkar ${ }^{1 \star \star \star}$, V.S. Reshetnik ${ }^{1}$, H.Y. Zemlianukhina \\ 1 \\ 1- National Technical University of Ukraine Igor Sikorsky Kyiv Polytechnic Institute, \\ pr. Peremohy, 37, Kyiv, 03056, Ukraine, \\ e-mail: sburyan18@gmail.com \\ 2- School of Engineering, University of Warwick, \\ Coventry, CV4 7AL, United Kingdom \\ e-mail: O.Kiselychnyk@warwick.ac.uk \\ * ORCID ID : https://orcid.org/0000-0002-4947-0201 \\ ** ORCID ID : https://orcid.org/0000-0001-5688-2688 \\ *** ORCID ID : https://orcid.org/0000-0002-9576-6433
}

\section{Abstract}

An observer based on an artificial neural network was designed. The observer determines the pumping unit performance depending on the operating point. Determination is based on the measured technological coordinates of the system and the pressure of the turbomechanism. Three neural networks were designed for three types of the productivity observer. The developed observer was investigated by the simulation method within different variations of disturbing actions, such as hydraulic resistance of the hydraulic system and geodetic pressure. A comparative analysis of three types of the productivity observer, built with using the pressure and different signals of the system with arbitrary change of hydraulic resistance was given. By the use of the pump unit efficiency observer, in addition to the results presented earlier, the efficiency of the productivity observer, which built with using different sensors, in water supply systems with two series-connected pump units, operating for filling the large tank, is 
researched. In the water supply system one pump speed is regulated, the other is unregulated. References 14, figures 5.

Key words: pumping unit, neural network, observer, parameter, turbomechanism.

Received: 22.11.2019

Accepted: 23.12 .2019

Published: 16.01 .2020

\section{References}

1. Cattaert A.E. High Pressure Pump Efficiency Determination from Temperature and Pressure Measurements. IEEE PES PowerAfrica Conference and Exposition.Johannesburg. South Africa, 16-20 July 2007. Pp. 1-8. DOI:

https://doi.org/10.1109/PESAFR.2007.4498076

2. Kallesoe C. S., Cocquempot V., Izadi-Zamanabadi R. Model based fault detection in a centrifugal pump application. IEEE transactions on control systems technology. 2006. Vol. 14. No 2. Pp. 204-215. DOI:

https://doi.org/10.1109/TCST.2005.860524

3. Bakman I., Gevorkov L. Speed control strategy selection for multi-pump systems. Proc. 56th International Scientific Conference on Power and Electrical Engineering of Riga Technical University

(RTUCON). 2015. Pp. 1-4. DOI:

https://doi.org/10.1109/RTUCON.2015.7343174

4. Bakman I., Gevorkov L., Vodovozov V. Efficiency control for adjustment of number of working pumps in multi-pump system. Proc. 9th International Conference on Compatibility and Power Electronics (CPE). 2015. Pp. 396-402. DOI: https://doi.org/10.11 09/CPE.2015.7231108

5. Vodovozov V. et al. Energy-efficient predictive control of centrifugal multi-pump stations. Elec tric Power Quality and Supply Reliability

(PQ). 2016. Pp. 233-238. DOI:

https://doi.org/10.1109/PQ.2016.7724119

6. Bakman I., Gevorkov L., Vodovozov V. Optimization of method of adjustment of productivity of multi-pump system containing directly connected motors. Electric Power Quality and Supply Reliability Conference (PQ). 2014. Pp. 209-214. DOI:

https://doi.org/10.1109/PQ.2014.6866812 
7. Lu Yan-juan, Yang Yi, Gu Hai-qin. Identification and self-tuning control of heat pump system based on neural network. IEEE Chinese Control and Decision Conference(CCDC). China, 28-30 May 2016. Pp. 6687-6691. DOI:

https://doi.org/10.1109/CCDC.2016.7532200

8. Pechenik N, Kiselychnyk O., Buryan S., Petukhova D. Sensorless control of water supply pump based on neural network estimation. Electrotechnic and Computer Systems. 2011. No 3. Pp. 462-466.

9. Qiang Zhu, Guoli Li, Rui Zhou Integrated model of water pump and electric motor based on BP neural network. Proc.10th Conference on Industrial Electronics and Applications (ICIEA). New Zealand, 15-17 June 2015. Pp. 1449-1452. DOI:

https://doi.org/10.1109/ICIEA.2015.7334335

10. Ahmed Rhif. A sliding mode observer for a sensorless pumping system. Proc. 7th International Conference on Modelling, Identification and Control

(ICMIC). Tunisia. 2015. Pp. 1-6. DOI:

https://doi.org/10.1109/ICMIC.2015.7409429

11. Burian S., Pechinik M., Pushkar M., Tytarenko A. Investigation of the Pump Unit Control System With the Neural Network Productivity Estimator. Proc. 6th International Conference on Energy Smart Systems

Ukraine. 2019. Pp. 298-302. DOI:

(ESS). Kyiv,

https://doi.org/10.1109/ESS.2019.8764176

12. Buryan S., Pechenik M., Zemlianukhina H. Development and research of the neural network pump efficiency observer based on the programmable logic integral scheme. Bulletin of Vinnitsa Polytechnic Institute

. 2018. No. 2. Pp.68-73. (Ukr)

13. Leonhard W. Control of Electrical Drives. Springer. Verlag, Berlin. 1996. 420 p. DOI: https:/ /doi.org/10.1007/978-3-642-97646-9

14. Buryan S., Pechenik M., Zemlianukhina H., Babarova A. Investigation of electromechanical automation system serially connected pumping units work in the package Simhydraulics. Bulleti $n$ of Kharkiv Petro Vasylenko National Technical University of Agriculture . 2019. No. 204. Pp.68-73. (Ukr)

\section{PDF}

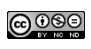

This work is licensed under a Creative Commons Attribution-NonCommercial-NoDerivatives 4.0 International License 
